\title{
Observations on the Response of Gros Michel Banana Plants in Sand Cultures to Different Proportions of Various Cations and Anions
}

\author{
E. Hernández Medina and M. A. Lugo López ${ }^{1}$ \\ INTRODUCTION
}

Bananas have always been an important item in Puerto Rican agriculture. The Gros Michel variety is generally preferred by consumers of fresh fruit, both locally and abroad. Production has declined markedly, mainly because of the incidence of the Fusarium wilt. Local research on factors affecting banana production has been limited. In an attempt to lay a basis for further fertilizer studies, fundamental greenhouse research was initiated on the nutrition of the Gros Michel banana. This paper reports on two studies concerning the nutrient balance of the banana plant, involving variations in anions such as nitrates, phosphates, and sulfates as well as in such cations as potassium, calcium, and magnesium.

\section{PROCEDURE}

Banana rhizomes (var. Gros Michel) selected for uniformity in size and shape were planted in purified quartz sand in 5-gallon coffee-urn liners. When rhizomes developed into small vigorous plants two experiments were started.

In the first experiment, the anion concentrations $\left(\mathrm{NO}_{3}, \mathrm{PO}_{4}, \mathrm{SO}_{4}\right)$ of the nutrient solutions supplied to the banana plants were varied with respect to one another, while the cation concentrations ( $\mathrm{K}, \mathrm{Ca}, \mathrm{Mg}$ ) remained constant. In the second experiment, the cation concentrations of the nutrient solutions were varied in relation to one another, while the anion concentrations remained constant. The triangulation technique followed by Hammer $(5)^{2}$ was adopted for preparing the nutrient solutions. For both anion- and cation-variation experiments six stock solutions were prepared with molar concentrations as shown in table 1 (5). Each of the three anion stock solutions contained one major anion, but was similar in cation composition to the other anion stock solutions. Each of the three cation stock solutions contained one major cation, but was likewise similar in composition to the other cation stock solutions.

The stock solutions were combined by eighths to give a range of 16 solutions of varying anion concentrations and 16 of varying cation con-

${ }^{1}$ Agronomist and Soil Scientist and Associate Director, respectively, Agricultural Experiment Station, Mayagüez Campus, University of Puerto Rico, Río Piedras, P.R.

${ }^{2}$ Italic numbers in parentheses refer to Literature Cited, p. 315. 
centrations. Figures 1 and 2 show the position in the anion and cation triangles occupied by the 16 solutions. They are identified by treatment numbers (T-1, T-2 … T-16) inside the heavy dark lines of the triangles.

TABLE 1.-Molar concentration of individual salts of anion and cation stock solutions ${ }^{1}$

\begin{tabular}{l|l|r}
\hline Symbol & \multicolumn{1}{|c}{ Salt } & Molarity \\
\hline \multirow{2}{*}{$\mathrm{A}$} & Anion stock solutions \\
\hline & $\mathrm{KNO}_{3}$ & \\
\hline \multirow{2}{*}{$\mathrm{Mg}\left(\mathrm{NO}_{3}\right)_{2}$} & .0045 \\
$\mathrm{Ca}\left(\mathrm{NO}_{3}\right)_{2}$ & .0060 \\
& $\mathrm{KH}_{2} \mathrm{PO}_{4}$ & .0045 \\
$\mathrm{MgHPO}_{4}$ & .0045 \\
& $\mathrm{Ca}\left(\mathrm{H}_{2} \mathrm{PO}_{4}\right)_{2}$ & .0060 \\
& $\mathrm{~K}_{2} \mathrm{SO}_{4}$ & .0045 \\
$\mathrm{MgSO}_{4}$ & .0045 \\
$\mathrm{CaSO}_{4}$ & .0060 \\
\hline
\end{tabular}

Cation stock solutions

\begin{tabular}{l|l|r}
\hline \multirow{2}{*}{$\mathrm{D}$} & $\mathrm{KNO}_{3}$ & 0.0045 \\
& $\mathrm{~K}_{2} \mathrm{SO}_{4}$ & .0045 \\
$\mathrm{KH}_{2} \mathrm{PO}_{4}$ & .0045 \\
$\mathrm{Ca}\left(\mathrm{NO}_{3}\right)_{2}$ & .0060 \\
$\mathrm{CaSO}$ & .0060 \\
& $\mathrm{Ca}\left(\mathrm{H}_{2} \mathrm{PO}_{4}\right)_{2}$ & .0060 \\
& $\mathrm{Mg}\left(\mathrm{NO}_{3}\right)_{2}$ & .0045 \\
$\mathrm{MgSO}$ & .0045 \\
& $\mathrm{MgHPO}_{4}$ & .0045 \\
\hline
\end{tabular}

${ }^{1}$ Each stock solution contained: 1.0 p.p.m. Fe as $\mathrm{FeSO}_{4} \cdot 7 \mathrm{H}_{2} \mathrm{O}, 0.5$ p.p.m. Mn as $\mathrm{MnSO}_{4} \cdot 4 \mathrm{H}_{2} \mathrm{O}, 0.5$ p.p.m. B as $\mathrm{H}_{3} \mathrm{BO}_{3}, 0.1$ p.p.m. $\mathrm{Zn}$ as $\mathrm{ZnSO}_{4} \cdot 7 \mathrm{H}_{2} \mathrm{O}, 0.02$ p.p.m. Ca as $\mathrm{CaSO}_{4} \cdot 2 \mathrm{H}_{2} \mathrm{O}$.

During the first 2 weeks in the crocks, the banana rhizomes were supplied only with demineralized water. For the following 2 weeks they received a complete one-half-strength nutrient solution. By the end of this period relatively uniform plants had developed and nutrient treatments were started. The slop-culture technique was used to supply nutrients to the plants. Once a week the sand in each culture was flushed with demineralized water to avoid concentration of salts in the root zone. This was immediately 
followed by application of fresh nutrients to the plants, depending on treatment differentials. Four plants were used in each treatment.

Five months after the nutrient-treatment differentials were imposed, observations and measurements were made on the growth and develop-

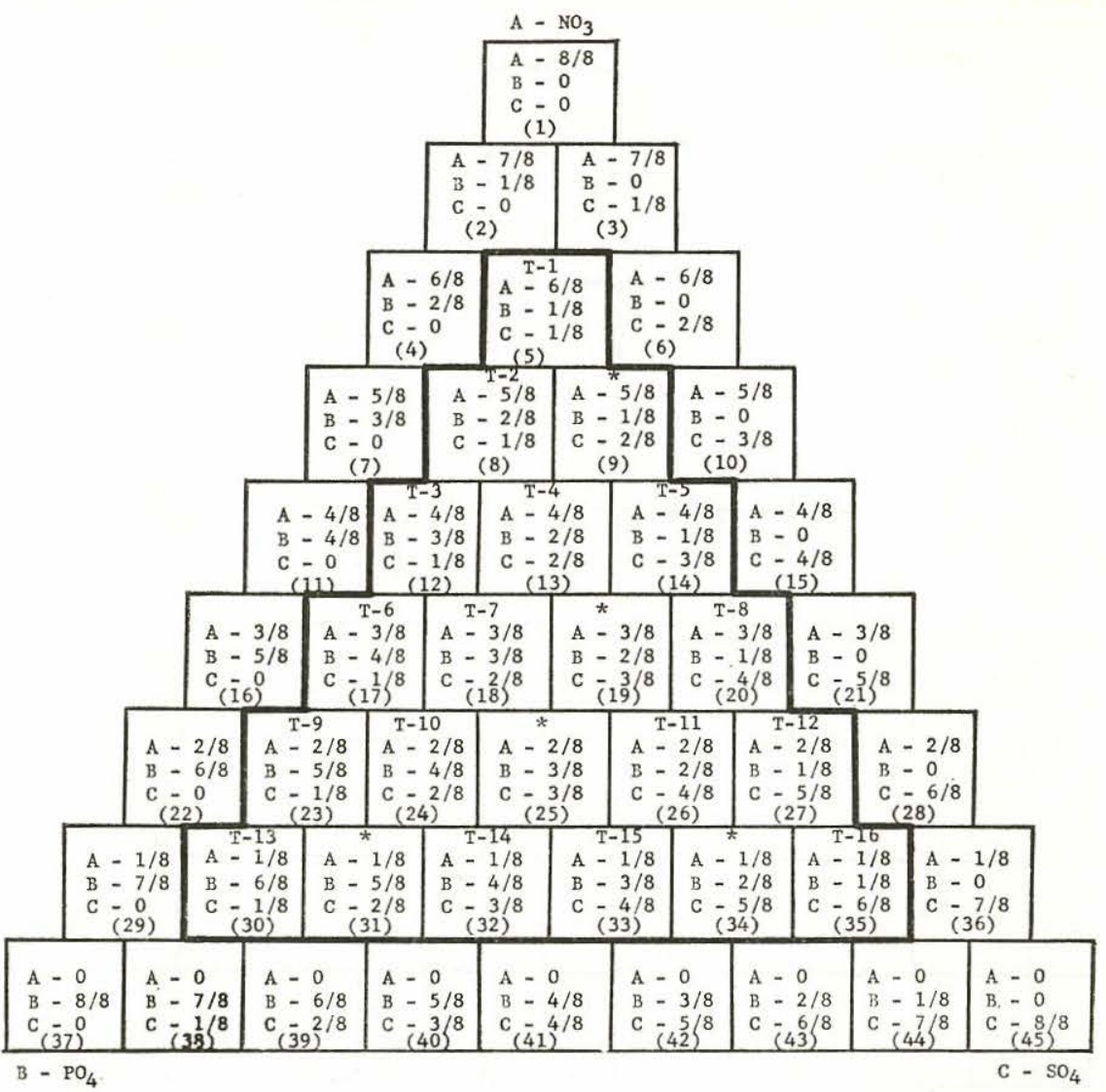

FIG. 1.-Triangle showing position and proportionate parts of anions of nutrient solutions selected for the anion-variation experiment with cationsremaining constant. * Nutrient solutions discarded in addition to those outside the dark lines.

ment of the plants. Measurements of height of plants, stem diameter at the base, number of leaves, and length and width of the second top leaf were made. Observations were recorded as to the general appearance of the plants. The appearance was evaluated on the basis of giving a value of 1 to poorly developed plants, 2 to fairly well-developed plants, 3 to good plants, and 4 to exceedingly well-developed plants. 


\section{RESULTS AND DISCUSSION}

The results of the evaluation of the growth criteria for banana plants grown in sand cultures using nutrient solutions where nitrate, phosphate, and sulfate levels were varied, while cations remained constant, are given

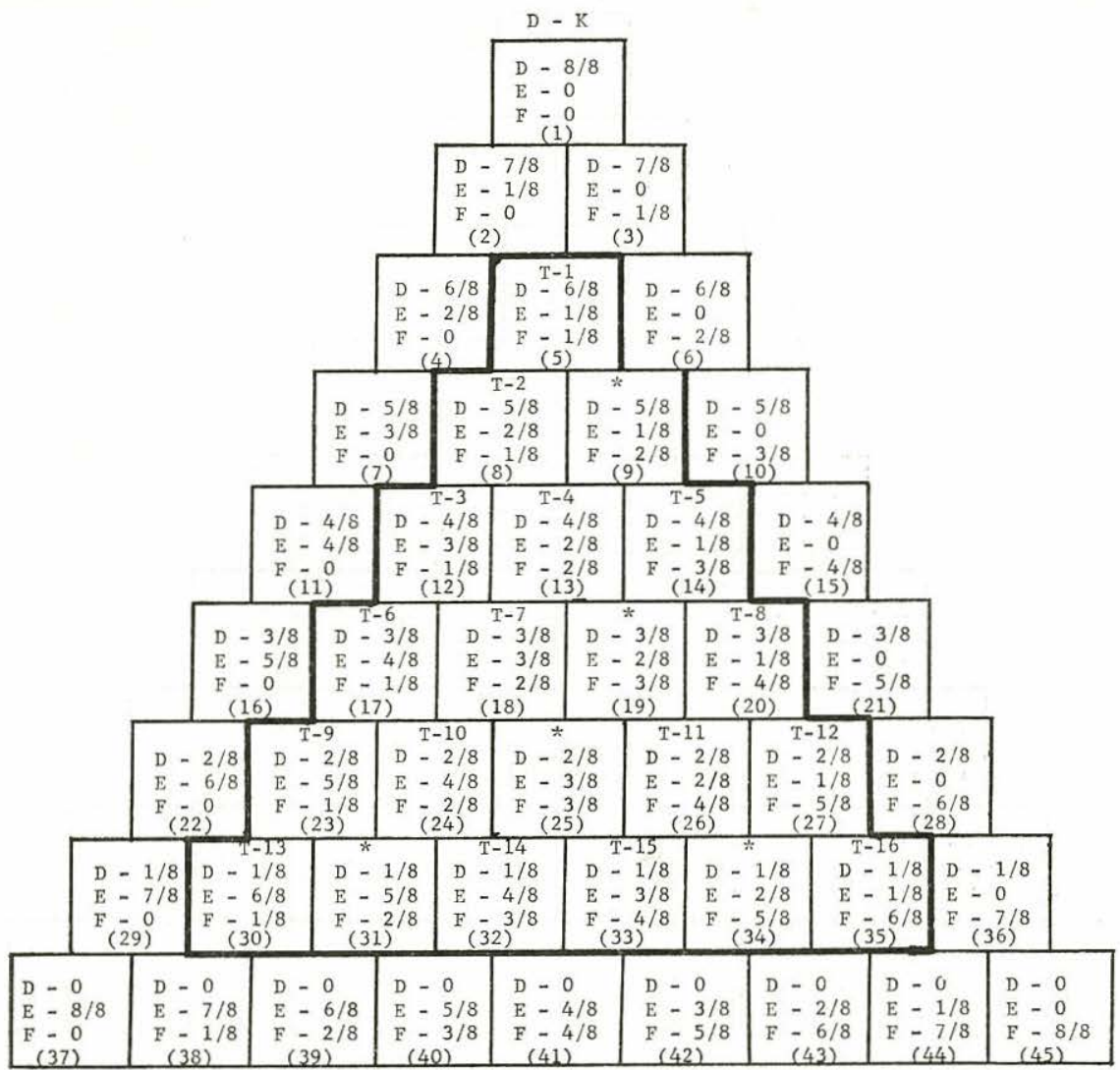

$\mathrm{E}-\mathrm{Ca}$

$\mathrm{F}-\mathrm{Mg}$

FIG. 2.-Triangle showing position and proportionate parts of cations of nutrient solutions selected for the cation-variation experiment with anions remaining constant. * Nutrient solutions discarded in addition to-those outside the dark lines.

in table 2. It is apparent from the data that banana plants developed better as a whole when grown at relatively high nitrate levels and low phosphates than when grown at high levels of both nutrients. In general, at a given nitrate level, a decrease in the phosphate concentration induced a more normal plant metabolism. The reciprocal relationship between 
nitrogen and phosphorus in plant nutrition has been pointed out by other investigators $(3,6,8)$.

The results concerning the growth of the banana plants when different levels of potassium, calcium, and magnesium were used, while keeping the anion concentrations constant, are given in table 3 . In general, it appears that when potassium was supplied in numerical ratios ranging between 3 and 6 , with other cation variations, the growth and development of

TABLE 2.-Response of banana plants (var. Gros Michel) grown in different proportions of nitrate, phosphate, and sulfate in sand culture-anion-

variation experiment

\begin{tabular}{|c|c|c|c|c|c|c|c|c|c|}
\hline \multicolumn{4}{|c|}{$\begin{array}{c}\text { Treatment-Proportional } \\
\text { part of cations in nutrient } \\
\text { solutions- }\end{array}$} & \multirow{2}{*}{$\begin{array}{c}\text { Height of } \\
\text { plants }\end{array}$} & \multirow{2}{*}{$\begin{array}{c}\text { Stem } \\
\text { diameter }\end{array}$} & \multirow[t]{2}{*}{ Leaves } & \multicolumn{2}{|c|}{$\begin{array}{l}\text { Second leaf } \\
\text { from top }\end{array}$} & \multirow{2}{*}{$\begin{array}{l}\text { Appearance } \\
\text { of plants }{ }^{1}\end{array}$} \\
\hline No. & $\mathrm{NO}_{3}$ & $\mathrm{PO}_{4}$ & $\mathrm{SO}_{4}$ & & & & Length & Width & \\
\hline & & & & Inches & Inches & Number & Inches & Inches & \\
\hline 1 & 6 & 1 & 1 & 37.0 & 2.59 & 13.7 & 35.9 & 13.2 & 3.2 \\
\hline 2 & 5 & 2 & 1 & 34.8 & 2.40 & 13.5 & 37.2 & 13.2 & 3.5 \\
\hline 3 & 4 & 3 & 1 & 34.1 & 2.09 & 13.2 & 31.7 & 12.4 & 2.7 \\
\hline 4 & 4 & 2 & 1 & 31.6 & 2.25 & 14.0 & 32.9 & 13.1 & 3.2 \\
\hline 5 & 4 & 1 & 3 & 37.7 & 2.82 & 13.7 & 39.1 & 14.6 & 4.0 \\
\hline 6 & 3 & 4 & 1 & 33.2 & 2.29 & 12.7 & 33.0 & 12.5 & 3.0 \\
\hline 7 & 3 & 3 & 2 & 32.7 & 2.12 & 12.5 & 33.5 & 12.2 & 3.5 \\
\hline 8 & 3 & 1 & 4 & 38.1 & 2.60 & 13.7 & 37.6 & 14.2 & 4.0 \\
\hline 9 & 2 & 5 & 1 & 31.4 & 1.99 & 11.0 & 30.2 & 11.9 & 2.0 \\
\hline 10 & 2 & 4 & 2 & 31.5 & 2.42 & 12.7 & 33.5 & 13.5 & 3.0 \\
\hline 11 & 2 & 2 & 4 & 33.0 & 2.38 & 13.0 & 35.0 & 14.0 & 3.2 \\
\hline 12 & 2 & 1 & 5 & 31.0 & 2.10 & 13.5 & 31.2 & 12.4 & 2.7 \\
\hline 13 & 1 & 6 & 1 & 25.1 & 1.54 & 8.7 & 24.4 & 9.1 & 1.7 \\
\hline 14 & 1 & 4 & 3 & 33.0 & 2.10 & 10.7 & 33.7 & 12.7 & 2.0 \\
\hline 15 & 1 & 3 & 4 & 27.6 & 2.12 & 10.7 & 28.0 & 10.7 & 2.0 \\
\hline 16 & 1 & 1 & 6 & 27.2 & 1.95 & 12.5 & 28.5 & 11.5 & 2.0 \\
\hline
\end{tabular}

${ }^{1}$ See text for explanation of numerical values.

banana plants was more favorable than in plants grown in sand cultures where potassium was supplied in numerical ratios ranging between 1 and 3 . From the relative proportions of cations in the various treatments, and the growth-criteria measurements, it is also apparent that, when calcium was in greater proportion than potassium in the sand media, plant metabolism was affected to a much greater extent than when magnesium was in greater proportion than potassium. This fact points to the possible greater antagonistic action between calcium and potassium than between magnesium and potassium. The importance of proper balance between the three major bases has been shown by several investigators $(1,2,4,7)$. 


\section{SUMMARY}

Greenhouse studies with Gros Michel bananas in sand cultures were conducted in two experiments. In one, nitrates, phosphates, and sulfates were varied while cations were kept constant. In another, potassium, calcium, and magnesium concentrations were variable while anions were constant. Measurements of height, stem diameter, number of leaves, and length and width of the second topmost leaf were taken when the plants were 6 months old. The general appearance of the plants was also

TABLE 3.-Response of banana plants (var. Gros Michel) grown in different proportions of potassium, calcium, and magnesium in sand culture-cation-variation experiment

\begin{tabular}{|c|c|c|c|c|c|c|c|c|c|}
\hline \multicolumn{4}{|c|}{$\begin{array}{l}\text { Treatment-Proportional } \\
\text { part of cations in nutrient } \\
\text { solutions- }\end{array}$} & \multirow{2}{*}{$\begin{array}{c}\text { Height of } \\
\text { plants }\end{array}$} & \multirow{2}{*}{$\begin{array}{c}\text { Stem } \\
\text { diameter }\end{array}$} & \multirow{2}{*}{ Leaves } & \multicolumn{2}{|c|}{$\begin{array}{l}\text { Second leaf } \\
\text { from top }\end{array}$} & \multirow{2}{*}{$\begin{array}{l}\text { Appearance } \\
\text { of plants }^{1}\end{array}$} \\
\hline No. & $\mathrm{K}$ & $\mathrm{Ca}$ & $\mathrm{Mg}$ & & & & Length & Width & \\
\hline & & & & Inches & Inches & Number & Inches & Inches & \\
\hline 1 & 6 & 1 & 1 & 32.3 & 2.03 & 13.3 & 35.0 & 13.3 & 3.0 \\
\hline 2 & 5 & 2 & 2 & 33.0 & 2.16 & 13.0 & 37.3 & 14.6 & 3.6 \\
\hline 3 & 4 & 3 & 1 & 39.3 & 1.95 & 12.6 & 31.0 & 11.6 & 3.0 \\
\hline 4 & 4 & 2 & 2 & 32.6 & 2.41 & 13.0 & 36.3 & 13.0 & 3.3 \\
\hline 5 & 4 & 1 & 3 & 30.6 & 2.10 & 13.3 & 31.0 & 12.0 & 2.6 \\
\hline 6 & 3 & 4 & 1 & 24.3 & 1.51 & 10.3 & 26.0 & 10.0 & 1.6 \\
\hline 7 & 3 & 3 & 2 & 31.0 & 2.22 & 13.0 & 34.0 & 13.6 & 3.0 \\
\hline 8 & 3 & 1 & 4 & 38.6 & 2.08 & 13.0 & 32.0 & 12.3 & 3.3 \\
\hline 9 & 2 & 5 & 1 & 25.3 & 1.41 & 10.3 & 25.0 & 9.6 & 1.6 \\
\hline 10 & 2 & 4 & 2 & 25.0 & 1.65 & 11.3 & 27.0 & 10.3 & 2.0 \\
\hline 11 & 2 & 2 & 4 & 33.0 & 2.47 & 13.6 & 36.3 & 13.6 & 3.0 \\
\hline 12 & 2 & 1 & 5 & 33.3 & 2.16 & 13.6 & 31.0 & 12.3 & 3.0 \\
\hline 13 & 1 & 6 & 1 & 17.0 & 1.10 & 8.6 & 18.6 & 7,0 & 1.0 \\
\hline 14 & 1 & 4 & 3 & 27.0 & 1.76 & 11.0 & 23.6 & 10.3 & 2.3 \\
\hline 15 & 1 & 3 & 4 & 28.8 & 1.89 & 11.6 & 28.0 & 10.6 & 2.0 \\
\hline 16 & 1 & 1 & 6 & 25.6 & 1.85 & 12.3 & 27.0 & 10.3 & 2.0 \\
\hline
\end{tabular}

${ }^{1}$ See text for explanation of numerical values.

evaluated. At a given nitrate level a more normal metabolism was possible when phosphate concentration decreased. High potassium favored better plant development. The data suggest a greater antagonistic effect between calcium and potassium than between magnesium and potassium.

\section{RESUMEN}

Se informan aquí los datos obtenidos de dos experimentos con la variedad de guineo Gros Michel sembrados en arena y en invernadero. En un experimento se variaron las concentraciones de nitrato, fosfatos y sulfatos, mientras que los cationes se mantuvieron constantes. En otro, se variaron 
las concentraciones de potasio, calcio y magnesio y se mantuvieron los aniones constantes. Cuando las plantas tenían 6 meses, se tomó un récord de su altura, diámetro del tallo, número de hojas y largo y ancho de la segunda hoja superior. Se evaluó, además, la apariencia general de las plantas. Los datos revelaron que a un nivel dado de nitratos el metabolismo de la planta es más normal cuando se reduce la concentración de fosfatos, y que los altos niveles de potasio favorecen un mejor desarrollo de la planta. Los datos también sugieren un mayor antagonismo fisiológico entre el calcio y el potasio que entre el magnesio y el potasio.

\section{LITERATURE CITED}

1. Cain, I. C., Some interrelationships between calcium, magnesium, and potassium, in one-year-old McIntosh apple trees grown in sand cultures, Proc. Amer. Soc. Hort. Sci. 51: 1-12, 1948.

2. Carolus, R. L., Effects of certain ions, used singly and in combination, on the growth and potassium, calcium and magnesium absorption of the bean plant, Plant Physiol. 13: 349-363, 1938.

3. Cullinan, F. P., and Batjer, L. P., Nitrogen, phosphorus, and potassium interrelationships in young peach and apple trees, Soil Sci. 55: 49-60, 1943.

4. Davidson, O. W., and Blake, M. A., Nutrient deficiency and nutrient balance with the peach, Proc. Amer. Soc. Hort. Sci. 35: 339-46, 1937.

5. Hammer, C. L., Growth responses of Biloxi soybeans to variation in relative concentrations of phosphate and nitrate in the nutrient solution, Bot. Gaz. 101: $637-49,1940$.

6. Kenworthy, A. L., and Galligan, G. M., Interrelationships between the nutrient content of soil, leaves, and trunk circumferences of peach trees, Proc. Amer. Soc. Hort. Sci. 51: 209-15, 1948.

7. Lilleland, O., and Brown, J. G., The potassium nutrition of fruit trees; II Leaf analyses, Proc. Amer. Soc. Hort. Sci. 36: 91-8, 1939.

8. Waltman, C. S., The effect of nitrogen and phosphorus on growth of apple and peach trees in sand cultures, Ky. Agr. Exp. Sta. Bul. 410, 1940. 